\title{
Crystal structure of $\left(\mathrm{Cu}_{0.51} \mid \mathrm{n}_{0.49}\right)_{\mathrm{tet}}\left[\mathrm{Cr}_{1.74} \mid \mathrm{n}_{0.26}\right]_{\text {oct }}$ $\mathrm{Se}_{4}$ selenospinel, $\mathrm{Cu}_{0.51} \mathrm{In}_{0.75} \mathrm{Cr}_{1.74} \mathrm{Se}_{4}$
}

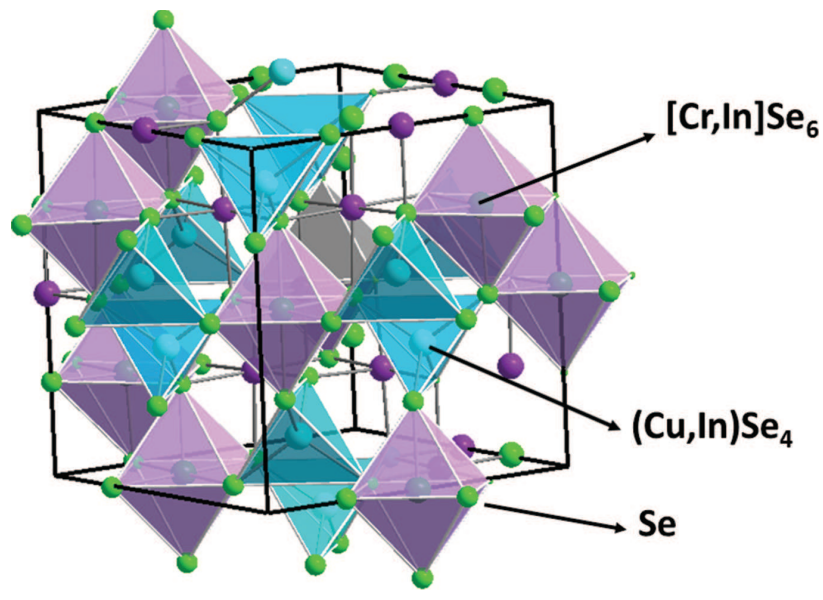

https://doi.org/10.1515/ncrs-2018-0426

Received October 14, 2018; accepted December 17, 2018; available online January 24, 2019

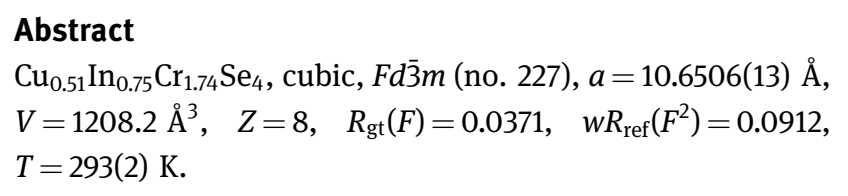

\section{CCDC no.: 1861215}

The crystal structure is shown in the figure. Tables 1 and 2 contain details on crystal structure and measurement conditions and a list of the atoms including atomic coordinates and displacement parameters.

\section{Source of material}

$\mathrm{Cu}_{0.51} \mathrm{In}_{0.75} \mathrm{Cr}_{1.74} \mathrm{Se}_{4}$ was prepared by directly combining highpurity elemental powders (99.99\%, Aldrich) in stoichiometric amounts. All manipulations were carried out under argon atmosphere. The reaction mixtures were sealed in evacuated quartz ampoules and placed in a programmable furnace. The ampoules were then slowly heated at a rate of $2.5^{\circ} \mathrm{C} / \mathrm{min}$, from room temperature until $500{ }^{\circ} \mathrm{C}$ for 2 hours, followed by

*Corresponding author: Antonio Galdámez, Universidad de Chile, Facultad de Ciencias, Departamento de Química, Casilla 653, Santiago Chile, e-mail: agaldamez@uchile.cl

Silvana Moris: Universidad Catolíca del Maule, Vicerectoria de Investigacion y Postgrado, Talca, Chile

Patricia Barahona: Universidad Catolíca del Maule, Facultad de Ciencias Basícas, Talca, Chile
Table 1: Data collection and handling.

\begin{tabular}{ll}
\hline Crystal: & Black prism \\
Size: & $0.05 \times 0.04 \times 0.04 \mathrm{~mm}$ \\
Wavelength: & Mo $K \alpha$ radiation $(0.71073 \AA)$ \\
$\mu:$ & $31.6 \mathrm{~mm}^{-1}$ \\
Diffractometer, scan mode: & D8 VENTURE Bruker AXS, \\
$\theta_{\text {max }}$, completeness: & $30.0^{\circ},>99 \%$ \\
$N(h k l)_{\text {measured }}, N(h k l)_{\text {unique }}, R_{\text {int }}:$ & $1089,109,0.040$ \\
Criterion for $I_{\text {obs }}, N(h k l)_{\text {gt }}:$ & $I_{\text {obs }}>2 \sigma\left(I_{\text {obs }}\right), 109$ \\
$N(\text { param })_{\text {refined }}:$ & 10 \\
Programs: & Bruker [1], SHELX [2], Olex2 [3], \\
& DIAMOND [4]
\end{tabular}

Table 2: Fractional atomic coordinates and isotropic or equivalent isotropic displacement parameters $\left(\AA^{2}\right)$.

\begin{tabular}{|c|c|c|c|c|}
\hline Atom & $x$ & $y$ & $z$ & $U_{\text {iso }} * / U_{\text {eq }}$ \\
\hline $\mathrm{Cu} 1^{\mathrm{a}}$ & $1 / 8$ & $1 / 8$ & $1 / 8$ & $0.0031(11)$ \\
\hline $\ln 1^{b}$ & $1 / 8$ & $1 / 8$ & $1 / 8$ & $0.0031(11)$ \\
\hline $\mathrm{Cr} 2^{\mathrm{c}}$ & $1 / 2$ & $1 / 4$ & $1 / 4$ & $0.0082(13)$ \\
\hline $\ln 2^{d}$ & $1 / 2$ & $1 / 4$ & $1 / 4$ & $0.0082(13)$ \\
\hline Se1 & $0.26060(10)$ & $x$ & $x$ & $0.0085(7)$ \\
\hline
\end{tabular}

a heating-rate of $1{ }^{\circ} \mathrm{C} / \mathrm{min}$ up to the maximum temperature of $850^{\circ} \mathrm{C}$, and held for 7 days.

\section{Experimental details}

Three models were considered for the permutations of the metal atom positions in $(A)_{\text {tet }}[B]_{\text {oct }} S_{4}$ spinel-type: (1) indium and copper cations sharing the tetrahedral position $(\mathrm{A})_{\mathrm{tet}}-\mathrm{Site}$; (2) indium and chromium cations sharing octahedral $[\mathrm{B}]_{\mathrm{Oct}^{-}}{ }^{-}$ sites; and (3) indium sharing both tetrahedral (A) tet ${ }^{-}$and octahedral $[\mathrm{B}]_{\text {oct }}-\mathrm{sites}$. For the tetrahedral cation site, the sum of site occupation factors (SOF) was constrained to equal 1 (fully occupied) for $8 \mathrm{a}=(1-x) \mathrm{Cu}+x \mathrm{In}$. The sum of SOF in the octahedral cation site was constrained to equal 2 (fully occupied) for $16 \mathrm{~d}=(2-y) \mathrm{Cr}+y \mathrm{In}$. Moreover, cations sharing the same site were constrained to have identical thermal displacements. A careful examination of the structural details, such as the thermal equivalent isotropic displacements $U_{\text {eq }}$, occupation sites, $R_{\mathrm{gt}}$ and $w R_{\mathrm{ref}}$ indices provided a strong indication 
of crystal structure final refinement. The best convergence refinements was obtained in model (3).

\section{Comment}

The $(\mathrm{Cu}, \mathrm{In})_{\text {tet }}-\mathrm{Se}$ distances in $\left(\mathrm{Cu}_{0.51} \mathrm{In}_{0.49}\right)_{\text {tet }}\left[\mathrm{Cr}_{1.74} \mathrm{In}_{0.26}\right]_{\text {oct }} \mathrm{Se}_{4}$ were consistent with the bond lengths of $\mathrm{Cu}_{0.5} \mathrm{In}_{0.5} \mathrm{Cr}_{2.0} \mathrm{Se}_{4}$ (2.475 ̊) [5] and $\mathrm{Cu}_{0.46} \mathrm{In}_{0.54} \mathrm{Cr}_{2.08} \mathrm{Se}_{4}$ (2.433-2.507 $\AA$ ) [6]. The [Cr, In $]_{\text {oct }}$-Se $(2.5548 \AA$ ) bond distances are comparable with $[\mathrm{Cr}, \mathrm{M}]_{\text {oct }}$-Se bond lengths for $\mathrm{CuCr}_{1.5} \mathrm{Zr}_{0.5} \mathrm{Se}_{4}$ (2.538 $\mathrm{A}$ ) and

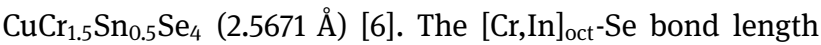
in the $\mathrm{CdCr}_{1.8} \mathrm{In}_{0.19} \mathrm{Se}_{4}$ compound is $2.55413 \AA$ [7]. Baur and Wildner et al. evaluated the degree of distortions of the tetrahedra and octahedra using distortion indices [8, 9]. These indices have been used in our research group for describing the polyhedra in $\mathrm{CuCr}_{2-\mathrm{x}} \mathrm{Sn}_{\mathrm{x}} \mathrm{Se}_{4}$ [6], $\mathrm{CuCr}_{2-\mathrm{x}} \mathrm{Ti}_{\mathrm{x}} \mathrm{Se}_{4}$ [10] and $\mathrm{CuCr}_{2-\mathrm{x}} \mathrm{Zr}_{\mathrm{x}} \mathrm{Se}_{4}$ [6]. In $\left(\mathrm{Cu}_{1-x} \mathrm{In}_{x}\right)_{\mathrm{tet}}\left[\mathrm{Cr}_{2-\mathrm{y}} \mathrm{In}_{\mathrm{y}}\right]_{\mathrm{Oct}} \mathrm{Se}_{4}$, the $(\mathrm{Cu}, \mathrm{In})_{\mathrm{tet}} \mathrm{Se}_{4}$ tetrahedra was ideal, with an angle of $109.47^{\circ}$. The $[\mathrm{Cr}, \mathrm{In}]_{\mathrm{oct}} \mathrm{Se}_{6}$ octahedron edge length distortion (EDL) indice is $4.5 \%$. This value of octahedral distortion is approximately twice that of the compounds previously reported: $\mathrm{CuCr}_{2-\mathrm{x}} \mathrm{Ti}_{\mathrm{x}} \mathrm{Se}_{4}, \mathrm{CuCr}_{2-\mathrm{x}} \mathrm{Sn}_{\mathrm{x}} \mathrm{Se}_{4}$ and $\mathrm{CuCr}_{2-\mathrm{x}} \mathrm{Zr}_{\mathrm{x}} \mathrm{Se}_{4}$. These materials obtained by ceramic synthesis present interesting magnetic properties such as other spinels substituted in A-site [11].

Acknowledgements: The authors thank FONDECYT Grant No. 1161020 and the Chilean-French International Associated Laboratory for Multifunctional Molecules and Materials (LIAM3-CNRS Nº1027).

\section{References}

1. Bruker. Analytical X-ray Instruments Inc., Madison, WI, USA (2000).

2. Sheldrick, G. M.: SHELXL97. Program for the refinement of crystal structures. University of Göttingen, Stuttgart (1997).

3. Dolomanov, O. V.; Bourhis, L. J.; Gildea, R. J.; Howard, J. A. K.; Puschmann, H.: OLEX2: a complete structure solution, refinement and analysis program. J. Appl. Crystallogr. 42 (2009) 339-341.

4. Brandenburg, K.: DIAMOND. Visual crystal structure information system. Ver. 3.0., Crystal Impact, Bonn, Germany (2004).

5. Yokoyama, H.; Chiba, S.: Preparation and magnetic properties of a new selenide spinel $\mathrm{Cu}_{1 / 2} \mathrm{In}_{1 / 2} \mathrm{Cr}_{2} \mathrm{Se}_{4}$. J. Phys. Soc. Jpn. 27 (1969) 505.

6. Pinto, C.; Galdámez, A.; Barahona, P.; Moris, S.; Peña, O.: Crystal structure, Raman scattering and magnetic properties of $\mathrm{CuCr}_{2-x} \mathrm{Zr}_{\mathrm{x}} \mathrm{Se}_{4}$ and $\mathrm{CuCr}_{2-x} \mathrm{Sn}_{\mathrm{x}} \mathrm{Se}_{4}$ selenospinels. J. Magn. Magn. Mater. 456 (2018) 160-166.

7. Skrzypek, D.; Malicka, E.; Waskowska, A.; Widuch, S.; Cichon, A.; Mydlarz, T.: Structural and magnetic properties of $\mathrm{Cd}_{\mathrm{x}} \mathrm{In}_{\mathrm{y}} \mathrm{Cr}_{\mathrm{z}} \mathrm{Se}_{4}$. J. Cryst. Growth 297 (2006) 419-425.

8. Baur, W. H.: The geometry of polyhedral distortions. Predictive relationships for the phosphate group. Acta Crystallogr. B30 (1974) 1195-1215.

9. Wildner, M.: On the geometry of $\mathrm{Co}(\mathrm{II}) 06$ in inorganic compounds. Z. Kristallogr. 202 (1992) 51-70.

10. Barahona, P.; Galdámez, A.; López-Vergara, F.; Manríquez, V.; Peña, 0.: Crystal structure and magnetic properties of titaniumbased $\mathrm{CuTi}_{2-x} \mathrm{M}_{\mathrm{x}} \mathrm{S}_{4}$ and $\mathrm{CuCr}_{2-x} \mathrm{Ti}_{\mathrm{x}} \mathrm{Se}_{4}$ chalcospinels. J. Solid State Chem. 212 (2014) 114-120.

11. Pinch, H. L.; Woods, M. J.; Lopatin, E.: Some new mixed A-site chromium chalcogenide spinels. Mater. Res. Bull. 5 (1970) 425-429. 